\title{
Nye læreplaner i norsk skole - hva og hvorfor?
}

I august i år ble nye læreplaner vedtatt for de første 11 årene i skolen. Naturfag (biologi, fysikk, kjemi og noe geofag) er ett av fagene som har fått ny læreplan. Det er et fellesfag for alle elever fram til og med 1. klasse i videregående skole (11. årstrinn). Denne høsten er læreplaner for programfag for de to siste årene i videregående opplæring sendt ut til høring. Det er første gang at læreplaner utvikles og sees i sammenheng for det 13-årige skoleløpet i Norge. De planene som er i bruk i norsk skole nå, ble innført fra 1994 i videregående skole (Reform 94) og i grunnskolen fra 1997 (L97).

Det nye læreplanverket (Kunnskapsløftet) består av flere deler:

- Generell del som er en arv fra den forrige læreplanen. Den angir overordnede mål for opplæringen og inneholder det verdimessige, kulturelle og kunnskapsmessige grunnlaget for grunnopplæringen

- Læringsplakaten handler om kvalitet i opplæringen, og den inneholder viktige prinsipper for skolens opplæringsvirksomhet

- Fag- og timefordeling angir hvilke fag som skolen skal gi undervisning i og timetall (i hele timer, og ikke leksjoner) for hovedtrinn i grunnskolen og hvert årstrinn i videregående opplæring

- Læreplaner for fag angir formål, hovedområder, omtale av grunnleggende ferdigheter, kompetansemål og bestemmelser for sluttvurdering i faget.

Det er læreplaner for fag som blir omtalt i det følgende.

\section{BAKGRUNN OG FФRINGER FOR NYE LAEREPLANER}

Innholdet i skolen er satt på dagsorden i flere land enn Norge i løpet av de siste årene. Det har vært gjennomført en rekke nasjonale og internasjonale undersøkelser som har bidratt til å peke på utfordringer som det norske skolevesenet står overfor.

I forbindelse med starten på læreplanrevisjonen høsten 2004 sa statsråd Kristin Clemet:

"Ny kunnskap om elevenes faglige nivå viser positive resultater på en del områder, men kunne helt klart voert bedre på andre. Norske 15-åringer har gode engelskferdigheter sammenliknet med elever $i$ andre land, mens elevenes kompetanse $i$ lesing, matematikk og naturfag ligger rundt det internasjonale gjennomsnittet. En urovekkende stor gruppe elever tilegner seg ikke tilstrekkelige grunnleggende ferdigheter i løpet av skoletiden."

Her blir det påpekt mangelfulle grunnleggende ferdigheter hos norske elever: det å kunne utrykke seg muntlig, lese, skrive, regne og bruke digitale verktøy. Dette er redskaper for all annen læring og derfor avgjørende for videre utdanning og arbeid. Bestillingen til læreplangruppene var klar: Grunnleggende ferdigheter skal integreres i læreplaner for alle fag på det enkelte fags premisser og 
på relevante nivåer i opplæringsløpet.

Evalueringen av de gjeldende læreplaner har vist at de er for omfattende, spesielt i grunnskolen. I dag er strukturen i læreplanene for grunnskolen og videregående opplæring ulik, og enkelte læreplaner er dels overlappende eller preget av mangelfull sammenheng og progresjon. Den målformulerte planen er også for upresis til å fungere som grunnlag for vurdering. Signalene var klare fra departementet: Kunnskap skal stå i sentrum i de nye læreplanene for fag ved at alle målene skal formuleres som kompetansemål. Disse målene skal være tydeligere, men mindre detaljerte enn dagens mål. Lokalt skal det bli større frihet til å organisere skoledagen og fag og frihet i metodevalg. Kompetansemål skal bare formuleres etter 2., 4., 7. og 10. årstrinn og etter hvert år i videregående skole. Det betyr at det ligger et stort ansvar hos grunnskolene for å lage progresjon i fagstoffet innenfor tidsperioder på 2 eller 3 år.

\section{HVEM LAGER LAREPLANER I NORGE?}

Forslaget til læreplan i naturfag ble utviklet av en gruppe på seks personer som ble oppnevnt av Utdanningsdirektoratet, departementets utøvende organ. Disse representerte skoleverket og universitets- og høgskolesektoren. Dessuten var det viktig å ha med personer som representerte de ulike fagdisiplinene som utgjør naturfag. Undertegnede har ledet arbeidet med naturfagplanen. Vi fikk ca 3 mnd på å utvikle et forslag som ble levert til Utdanningsdirektoratet like før årsskiftet i 2004. Dette forslaget ble vesentlig bearbeidet og endret av Utdanningsdirektoratet, fordi planen var for detaljert og omfangsrik i følge direktoratet. Dette bearbeidete forslaget ble så lagt ut elektronisk til høring for alle som var interesserte i å si sin mening.

Uttalelsene fra høringsrunden var nokså entydige: Forslaget fra Utdanningsdirektoratet var for vagt, for lite presist og mange anbefalte at man heller brukte det planforslaget som læreplangruppa hadde utarbeidet. Dessuten fikk departementet sterk motbør på å flytte en time i naturfag fra ungdomstrinnet ned til barnetrinnet, der lærerkompetansen i naturfagene er mye svakere enn på ungdomstrinnet. Departementet og utdanningsdirektoratet tok høringen til følge og lot timetallet forbli uendret på ungdomstrinnet, og styrket timetallet på barnetrinnet med 1 time per uke. Den gruppa som fikk i oppdrag å lage et endelig forslag for naturfag, fikk frie tøyler til å ta hensyn til hovedtrendene i høringsuttalelsene. Medio august i år fastsatte statsråd Clemet de nye planene, blant annet for naturfag for de første 11 årene i skolen.

\section{HVA BLE SÅ RESULTATET FOR NATURFAG?}

Læreplanen for naturfag innledes med et formål som beskriver fagets hensikt i et individ- og samfunnsperspektiv slik at de vesentlige perspektivene og verdiene $\mathrm{i}$ faget synliggjøres. Faget er strukturert i hovedområder som det er formulert kompetansemål innenfor. Hovedområdene for naturfag i grunnskolen er:

- Forskerspiren

- Mangfold i naturen

- Kropp og helse

- Verdensrommet

- Fenomener og stoffer

- Teknologi og design

I 11. årstrinn eller Vg1, som er det offisielle navnet, er naturfag strukturert etter følgende hovedområder:

- Forskerspiren

- Bærekraftig utvikling (jfr. Mangfold i naturen)

- Ernæring og helse (jfr. Kropp og helse)

- Stråling og radioaktivitet (jfr. Fenomener og stoffer, Verdensrommet)

- Energi for framtiden (jfr. Fenomener og stoffer)

- Bioteknologi (jfr. Teknologi og design) 
Hovedområdene for $\mathrm{Vg} 1$ er valgt ut fra at dette er siste gang de fleste elevene har undervisning i naturfag, og læreplangruppa har derfor lagt størst vekt på den allmenndannende siden ved faget.

Det er spesielt to av hovedområdene fra grunnskolen som trenger en kommentar, fordi de representerer noe nytt i naturfaget i norsk skole: Forskerspiren og Teknologi og design.

\section{Forskerspiren}

Internasjonale undersøkelser har vist at norske elever ikke er så gode på prosesser i naturfag. Temaene som nevnes i Forskerspiren finner vi mer eller mindre tydelig formulert i den gjeldende læreplanen, men vi har ønsket å legge større vekt på denne siden ved naturfaget ved å formulere den som et eget hovedområde. Dersom vi leser engelske læreplaner, finner vi i flere sammenhenger begrepet The Nature of Science. Det er dette Forskerspiren handler om.

Hovedområdet beskrives slik i læreplanen:

"Naturvitenskapen framstår på to måter i naturfagundervisningen: som et produkt som viser den kunnskapen vi har $i$ dag, og som en prosess som dreier seg om naturvitenskapelige metoder for å bygge kunnskap. Prosessene omfatter hypotesedanning, eksperimentering, systematiske observasjoner, åpenhet, diskusjoner, kritisk vurdering, begrunnelser for konklusjoner og formidling. Forskerspiren skal ivareta disse dimensjonene i opplaeringen."

Hvordan er så dette uttrykt i kompetansemål i læreplanen? Nedenfor er eksempler fra kompetansemålene etter 7. årstrinn i grunnskolen:

\section{Mål for opplæringen er at eleven skal kunne}

- formulere spørsmål om noe han eller hun lurer på, lage en plan for å undersøke en

selvformulert hypotese, gjennomføre undersøkelsen og samtale om resultatet

- forklare hvorfor det er viktig å lage og teste hypoteser ved systematiske observasjoner og forsøk, og hvorfor det er viktig å sammenligne resultater

- bruke digitale hjelpemidler og naturfaglig utstyr ved eksperimentelt arbeid og feltarbeid

- trekke naturfaglig informasjon ut fra enkle naturfaglige tekster i ulike medier

- publisere resultater fra egne undersøkelser ved å bruke digitale verktøy

På tidligere årstrinn inneholder kompetansemålene formuleringer om undring, observasjon, bruke sansene, systematisere materiale og presentasjon av egne observasjoner. Når man sammenlikner Forskerspiren på de ulike hovedtrinnene, ser man en tydelig progresjon. Noen vil nok hevde at planen er for ambisiøs innen dette hovedområdet.

\section{Teknologi og design}

Det har vært arbeidet for å overbevise norske politikere om at Teknologi og design burde bli et nytt fag i norsk grunnskole. Dette arbeidet lyktes ikke. I Stortingets behandling ble det vedtatt at Teknologi og design skal være et flerfaglig emne der Naturfag, Matematikk og Kunst- og håndverk samarbeider.

Hovedområdet beskrives slik i læreplanen:

"Teknologi og design dreier seg om å planlegge, utvikle og framstille produkter til nytte $i$ hverdagen. Samspillet mellom naturvitenskap og teknologi står sentralt $i$ dette hovedområdet. Naturfaglige prinsipper vil voere et grunnlag for å forstå teknologisk virksomhet”.

Hvordan er så dette uttrykt i kompetansemål i læreplanen? Vi tar med eksempler fra kompetansemålene etter 4. årstrinn i grunnskolen: 


\section{Mål for opplæringen er at eleven skal kunne}

- planlegge, bygge og teste enkle modeller av byggkonstruksjoner og dokumentere prosessen fra idé til ferdig produkt

- beskrive konstruksjoner og samtale om hvorfor noen er mer stabile og tåler større belastning enn andre

- gjenkjenne og sammenligne bærende strukturer i ulike byggverk i nærmiljøet

I disse kompetansemålene er det lagt stor vekt på prosessene og at elevene skal knytte kunnskapen til observasjoner i lokalmiljøet.

\section{Grunnleggende ferdigheter i naturfag}

Grunnleggende ferdigheter er fra departementets side definert som:

- å kunne uttykke seg muntlig

- å kunne lese

- å kunne skrive

- å kunne regne

- å kunne bruke digitale verktøy

Disse er beskrevet generelt på fagets presmisser i de innledende avsnittene til læreplanen. De er også integrert i kompetansemålene slik at de er en del av fagkompetansen. Et par eksempler viser hva dette betyr for naturfag.

"A kunne bruke digitale verktøy $i$ naturfag dreier seg om å kunne benytte slike verktøy til utforskning, måling, visualisering, simulering, registrering, dokumentasjon og publisering ved forsøk og i feltarbeid. For å stimulere kreativitet, levendegjøre og visualisere naturfaglige problemstillinger er digitale animasjoner, simuleringer og spill gode hjelpemidler. Kritisk vurdering av nettbasert naturfaglig informasjon styrker arbeidet med faget. De digitale kommunikasjonssystemene gir muligheter for å drøfte naturfaglige problemstillinger."

I det neste avsnittet er ferdigheter i å skrive og i å bruke språket muntlig slått sammen:

"A kunne uttrykke seg muntlig og skriftlig $i$ naturfag inneboerer å presentere og beskrive egne opplevelser og observasjoner fra naturen. I naturfag er skriftlige rapporter fra eksperimenter, feltarbeid, ekskursjoner og fra teknologiske utviklingsprosesser sentrale. A kunne formulere spørsmål og hypoteser og å bruke naturfaglige begreper og uttrykksformer inngår $i$ dette. A argumentere for egne vurderinger og gi konstruktive tilbakemeldinger er viktig i naturfag."

Det betyr at det i naturfag ikke er likegyldig hvordan elever uttrykker seg skriftlig og muntlig. Dette skal vektlegges i naturfag, fordi naturfag sammen med andre fag skal bidra til at elevene blir bedre i grunnleggende ferdigheter, samtidig som elevene kan lære faget bedre ved å vektlegge grunnleggende ferdigheter i opplæringen.

\section{Programfag i videregående skole}

Denne høsten sender skoler og institusjoner inn høringsuttalelser om nye læreplaner i programfag i videregående skole. Dette er fag som elevene skal velge i 2. og 3. klasse (Vg2 og Vg3). Elevene har 15 timer til slike valg på hvert årstinn. Det er laget læreplanforslag i disse realfagene: Biologi, Fysikk, Kjemi, Matematikk, Informasjonsteknologi og to nye fag: Geofag og Teknologi og forskningslære. Disse planene er planlagt vedtatt i januar 2006. Da først vil vi vite om de to nye programfagene vil bli en del av norsk skole. 


\section{Implementering av Iæreplanene}

Implementeringen av læreplanene starter høsten 2006 og i 2008 skal Vg3 innføre de nye læreplanene. Norsk skole og norske lærere står overfor store utfordringer når de fra neste år skal ta i bruk den nye læreplanen i naturfag. Det er ikke bare de nye hovedområdene som byr på store utfordringer, men også lokal planlegging av en god og fornuftig progresjon i faget. Dersom ikke lærerne setter seg i førersetet og tar kommandoen på dette området, vil lærebøkene styre og legge premissene for tolkning av læreplanen. Departementet har ønsket noe annet. Spørsmålet er om dette er mulig med den mangel på naturfaglig kompetanse som er avdekket i norsk skole, spesielt på barnetrinnet.

Det legges opp til en storstilt kompetanseheving fra myndighetenes side. Det er antydet beløp i størrelsesorden 2-3 milliarder NOK. Myndighetene ønsker at det er skolenes egendefinerte behov som skal være utgangspunkt for denne kompetanseutviklingen. Spørsmålet er om skolene har bestillingskompetanse til å få de kursene og den utviklingen som trengs i forhold til nye planer. Det sies at det er de som har skoen på som vet hvor den trykker! Men når man ikke har noen sko på, så blir det kanskje ikke så lett...?

Under er en lenke til den nye læreplanen. Naturfag finner du på side 51.

http://www.odin.dep.no/filarkiv/255552/Lplan_260805.pdf 